\title{
Sourcing Fire Ash on Archaeological Sites in the Western and Northern Isles of Scotland, Using Mineral Magnetism
}

\author{
M.J. Church, ${ }^{1, *}$ C. Peters ${ }^{2}$ and C.M. Batt ${ }^{3}$ \\ ${ }^{1}$ Department of Archaeology, Durham University, South Road, Durham, \\ DH1 3LE, U.K. \\ ${ }^{2}$ School of Geography and Geosciences, Irvine Building, University of \\ St Andrews, St. Andrews, Fife, KY16 9AL, U.K. \\ ${ }^{3}$ Department of Archaeological Sciences, University of Bradford, \\ Bradford, BDr 1DP, U.K.
}

\begin{abstract}
The application of a new technique developed to identify different fuel sources from ash on nine archaeological sites in the Western and Northern Isles of Scotland is presented. The technique is based on variations observed in the mineral magnetic signatures that derive from the experimental burning of different fuels. The application of the technique is successful, demonstrating both uniformity and diversity in fuel use. A marked continuity of practice in fuel procurement is apparent over thousands of years from seven sites in Lewis, with well-humified peat the dominant fuel source. This implies a long-term stability in the division and tenure of the peatlands. Greater magnetic variation is displayed by the samples from Cladh Hallan, South Uist, and Scatness, Shetland, suggesting more diverse fuel procurement strategies were in operation at these sites. The uniformity and diversity in fuel types also has implications in terms of the residuality of plant remains from the fuel source within archaeobotanical assemblages recovered from the sites. (C) 2007 Wiley Periodicals, Inc.
\end{abstract}

\section{INTRODUCTION}

This paper discusses the application of a new technique developed to identify different fuel sources from ash on archaeological sites in the Western and Northern Isles of Scotland. The technique is based on variations observed in the mineral magnetic signatures that derive from the experimental burning of different fuels including well-humified peat, fibrous peat, peaty turf, and wood. Laboratory-based magnetic techniques have many applications within archaeology (e.g., Yates, 1988; Faßbinder and Stanjek, 1993). Dalan and Banerjee (1998) have highlighted the wide variety of these applications, with specific reference to understanding archaeological landscapes. Bellomo (1993), McClean and Kean (1993), Morinaga et al. (1999), Linford (2000), and Canti and Linford (2000) have all used magnetic techniques in the study of the archaeological remains of fires. Within Atlantic Scotland, a regional

*Corresponding author; E-mail: m.j.church@durham.ac.uk

Geoarchaeology: An International Journal, Vol. 22, No. 7, 747-774 (2007)

(C) 2007 Wiley Periodicals, Inc.

(3ILEY

Published online in Wiley Interscience (www.interscience.wiley.com). DOI:10.1002/gea.20185 
zone defined by Piggott (1966) and Batt and Dockrill (1998) have integrated magnetic susceptibilities, gradiometry, and archaeomagnetic data with other archaeological evidence to evaluate site formation processes and land management strategies at the multi-period site of Old Scatness, Shetland. Mineral magnetic enhancement has also been demonstrated in the eroding archaeological coastal sites of St. Boniface, Orkney (Peters and Thompson, 1999), and Galson, Lewis (Peters et al., 2000), the signal being fixed through burning on hearths and the subsequent spread of ash throughout the archaeological contexts.

The development of the technique was undertaken at the University of Edinburgh's Archaeological Research Centre at Calanais Farm (see Figure 1). From this center, an extensive program of survey and excavation throughout Lewis ran for over 15 years (the Calanais Archaeological Research Project: Harding, 2000). On many of the sites excavated, a detailed palaeoenvironmental sampling strategy was employed, with the primary aim of retrieving archaeobotanical and other ecofactual assemblages (Church, 2002a). Routine soil tests, including specific magnetic susceptibility $\left(\chi_{i n}\right)$, were also measured for each context sampled. This not only demonstrated the wide range of mineral magnetic signatures across contexts but also highlighted the role of ash from domestic hearths in the buildup of the site stratigraphy and ecofact taphonomy (cf. Peters et al., 2000; Church and Peters, 2004).

A program of experimental research was established to understand the production of these ash deposits and the different suites of archaeobotanical material held within them. Analysis was undertaken on the residues produced from replica domestic hearths over a period of six weeks in the summer of 1998. The aim of the experimentation was to establish the varying geoarchaeological signatures and archaeobotanical suites that were produced through the burning of different fuels. The research presented in this paper is based on the comparison of the experimental results and the mineral magnetic analysis of samples from a number of later prehistoric sites in the Western and Northern Isles of Atlantic Scotland dating to the first millenniums B.C. and A.D.

\section{EXPERIMENTAL RESEARCH BASIS}

Fuel procurement is an important research question within Atlantic Scotland (Armit, 1996; Dickson, 1998; Carter, 1998) and the wider North Atlantic (Simpson et al., 2003). Timber would have been a valued resource, as tree cover throughout the region was greatly reduced by the Iron Age (Birks, 1994; Fossit, 1996; Brayshay and Edwards, 1996; Lomax, 1997). Therefore, the use of timber and branch wood would have been reserved for internal structural furnishings and tools, and rarely used for fuel. Other fuels would have been burnt, and their gathering would have been an important component of the annual resource procurement strategy.

The identification of different fuel types also aids in the interpretation of archaeobotanical assemblages, as it allows the separation of those macrofossils that may have been introduced through the fuel from those plants relating to other human uses (Church, 2002a). The development of a fuel sourcing technique independent of the archaeobotanical assemblages was seen as an important tool for disentangling 

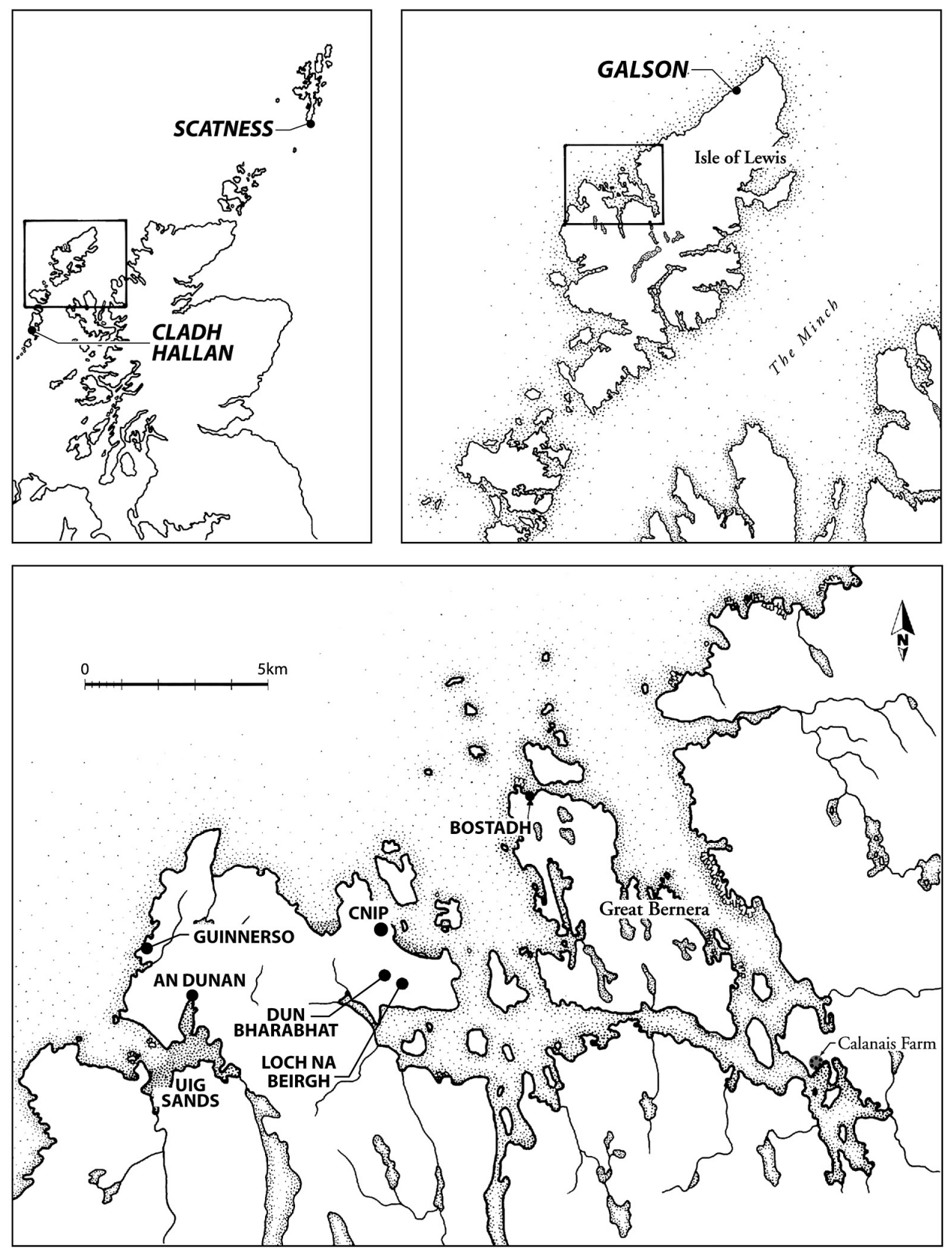

Figure 1. Location of archaeological sites sampled (reproduced with the permission of Ian Armit). 
the mixed carbonized plant macrofossil record of Atlantic Scotland (Bond, 1998; Church and Peters, 2004). Past research has shown that certain fuels introduce plant macrofossils from their primary ecosystems, for example from the grassland and heaths from cut turf (McClaughlin, 1980; Bottema, 1984; Dickson, 1994, 1998) and pasture represented in dung used as fuel (Miller and Smart, 1984; Anderson and Ertug-Yaras, 1998; Charles, 1998; Smith, 1998).

The choice of fuel sources for the experimentation was based on past research conducted on various sites in Atlantic Scotland. The techniques used included on-site archaeological observation of peat stacks and ash (cf. Harding and Gilmour, 2000), archaeobotanical analysis (Dickson, 1994, 1998; Boardman, 1995; Smith, 1999), and soil micromorphology (Carter, 1998, 1999; Schwenninger, 1999). Ethnographic observations (Martin, 1716; Fenton, 1978) and discussions with local people who still cut peat from their township peat banks also built up a picture of the fuel types used in the recent past. Four main fuel types were apparent from these various lines of evidence: (1) well-humified peat from the large tracts of blanket bog that covered the interior of Lewis for thousands of years; (2) peaty turf; (3) fibrous peat from the more shallow peat, usually found in the narrow coastal strip in which most of the archaeological sites and modern settlement are found; and (4) wood, including locally derived small roundwood as well as timber driftwood (Dickson, 1994). Other types of fuel could also have been used, including dung, seaweed, straw/hay, and other types of organic turf. However, it was felt that the four main fuel types outlined above would have formed the bulk of the fuel used, as archaeobotanical evidence of these other fuel types, such as burnt seaweed, were rarely found on the sites investigated on Lewis (cf. Church, 2002a and 2002b).

\section{METHODS}

\section{Replica Hearths}

Controlled and repeated burning of the four different fuel types within replica domestic hearths was carried out for 16 burning cycles, each of 3 days duration. Three replica hearths were constructed at Calanais Farm, based on the Late Iron Age three-sided hearths commonly uncovered in the Western Isle of Scotland (cf. Chapter 4 in Harding and Gilmour, 2000). Each hearth measured approximately $0.6 \times 0.4 \mathrm{~m}$, with hearth slabs of Lewisian gneiss, the basement local rock for much of Lewis. These slabs were placed into approximately $0.1 \mathrm{~m}$ of magnetically sterile machair sand. The fuel was taken from two areas: the peaty turf and fibrous-upper peat from near the township of Gearranan (U.K. National Grid Reference: NB 205 445) and the well-humified peat and wood from near Gearraidh na h-Aibhne (U.K. National Grid Reference: NB 265 307). All the peat types were cut in springtime and dried and stacked in the summer. The wood came from dead pine trees (Pinus sp.) from a plantation recently blighted by beetles. The fires were started by lighting dried lichen (Ramalina sp.) and pinewood chips (Pinus sp.). Only one fuel source was used throughout the period and the fires were kept going for the full three days. No attempt was made to monitor the 
atmospheric environment of the burning, as the experimentation was undertaken to replicate human action on domestic prehistoric sites rather than exact laboratory conditions.

The ash was allowed to cool before sampling. The color of the ash produced was first recorded in situ, using a Munsell color chart (1992). Multiple samples were then taken for mineral magnetic measurements and archaeobotanical analysis. A section line was set up through the center of the hearth, and half the ash excavated. Bulk and routine samples were taken for archaeobotanical and mineral magnetic analysis, respectively. The section was then drawn for each hearth sampled and in some cases close-interval $(2 \mathrm{~cm})$ samples taken through the ash and the underlying sand. The rest of the ash was then excavated and the ash from each fuel type dumped onto specially prepared areas covered by sterile beach sand, located in a sheltered area in Calanais farm. These dumps were bulk sampled for archaeobotanical analysis in the summer of 2000.

\section{SUMMARY OF FUEL ASH SOURCING THROUGH MINERAL MAGNETISM}

The detailed description of the experimental methodology and the results are described by Peters et al. (2001, 2002, 2004). A summary of the technique is presented here. Samples of the ash produced were taken for mineral magnetic analysis and sieved through a $63 \mu \mathrm{m}$ gauge to mechanically isolate the ash component, an important methodological step when comparing the experimental and archaeological samples (for more detail see Church, 2002a). Six room-temperature magnetic measurements were carried out on the modern ash residues of known fuel type:

1. Susceptibilities at low $(0.47 \mathrm{kHz})$ and high $(4.7 \mathrm{kHz})$ frequencies, measured using a Bartington MS2 susceptibility meter.

2. Anhysteretic remanent magnetizations (ARMs), grown using an adapted Molyneux AC demagnetizer and measured using a Molspin fluxgate magnetometer. Two measurements were made for each sample; the saturation (S)ARM was grown in a peak alternating field $\left[\times \mu_{0}\right]$ of $99 \mathrm{mT}$ superimposed on a direct field $\left[\times \mu_{0}\right]$ of $0.1 \mathrm{mT}$ and subsequent demagnetization of SARM in an alternating field $\left[\times \mu_{0}\right]$ of $40 \mathrm{mT}$.

3. Isothermal remanent magnetizations (IRMs), grown using a Molyneux pulse magnetizer and electromagnets and measured using a Molspin fluxgate magnetometer. The IRMs were grown in two fields $\left[\times \mu_{0}\right]$ of $60 \mathrm{mT}$ and the saturation (S)IRM in $1 \mathrm{~T}$.

The following magnetic parameters were determined from the six measurements for each sample: specific susceptibility $\left(\chi_{i n}\right)$, frequency dependent susceptibility $\left(\kappa_{\mathrm{fd}}\right)$, specific SARM, specific SIRM and the ratios $\mathrm{ARM}_{\text {demag40mT }} / \mathrm{SARM}, \mathrm{IRM}_{60 \mathrm{mT}} / \mathrm{SIRM}$, $\mathrm{SARM} / \chi_{i n}, \mathrm{SARM} / \mathrm{SIRM}$, and $\mathrm{SIRM} / \chi_{i n}$. The range of results can be seen in Table I. Further details of the procedures and applications of these mineral magnetic measurements and ratios can be found in Thompson and Oldfield (1986), Walden et al. 


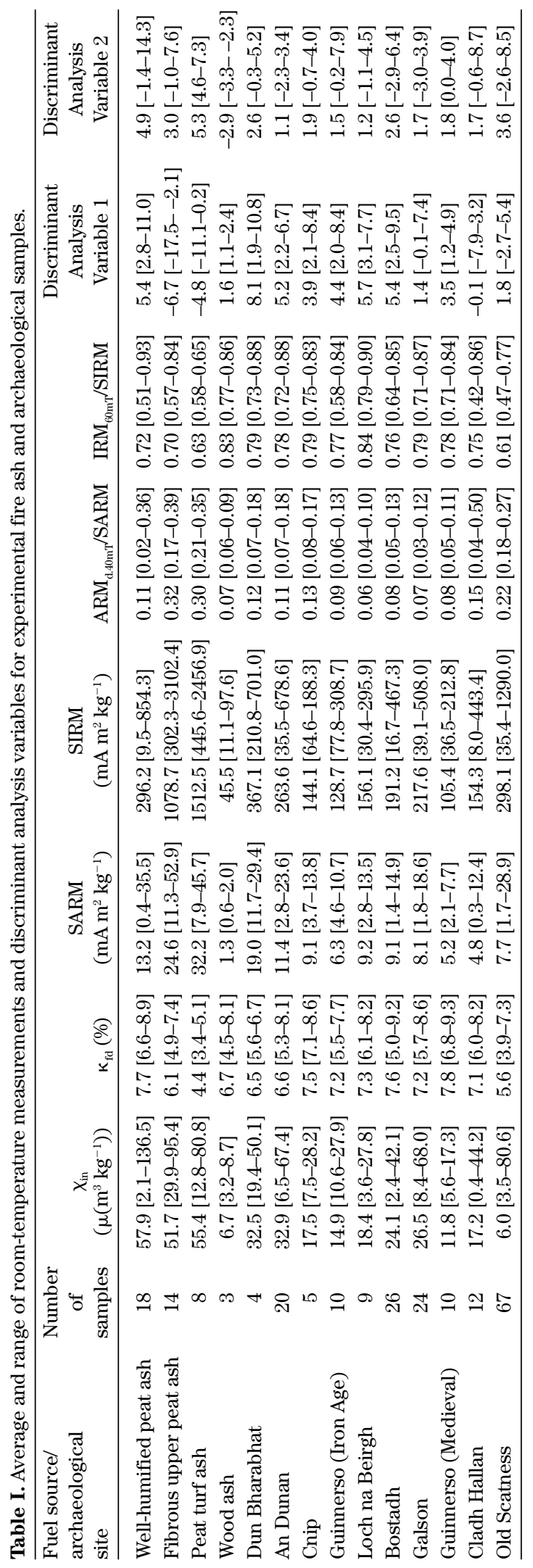


(1999), and Maher and Thompson (1999). The statistical package BMDP, subprogram $7 \mathrm{M}$ (Dixon, 1985) was used to carry out multivariate discriminant analysis on the magnetic parameters/ratios of the modern ash samples to find linear combinations of the data that show the greatest separation and least dispersion between the different fuel types:

Discriminant analysis variable $1=\left(a \times \chi_{\text {in }}\right)+\left(b \times \kappa_{\mathrm{fd}}\right)+(c \times \mathrm{SARM})+\cdots$ and

Discriminant analysis variable $2=\left(z \times \chi_{\text {in }}\right)+\left(y \times \kappa_{\mathrm{fd}}\right)+(x \times \mathrm{SARM})+\ldots$

The two resulting discriminant analysis variables produced the biplot in Figure 2. The biplot shows good discrimination between the well-humified peat ash and wood ash, with some overlap between the fibrous-upper peat ash and peat turf ash. By measuring the same six magnetic parameters on archaeological ash samples as for the modern ash samples, calculating the magnetic ratios, and finally using the already determined multiplication factors $a, b, c \ldots$ and $z, y, x \ldots$ for the two discriminant analysis variables, the archaeological ash samples can be superimposed onto the biplot in Figure 2 to allow comparison to the modern ash samples and give an estimate of fuel type.

A second method of distinguishing fuel types using their magnetic signatures of the resulting ash was developed from monitoring the variation of magnetic susceptibility with increasing temperature up to $700^{\circ} \mathrm{C}$ and cooling back to room temperature. The fibrous-upper peat ash and peat turf ash show characteristic drops in

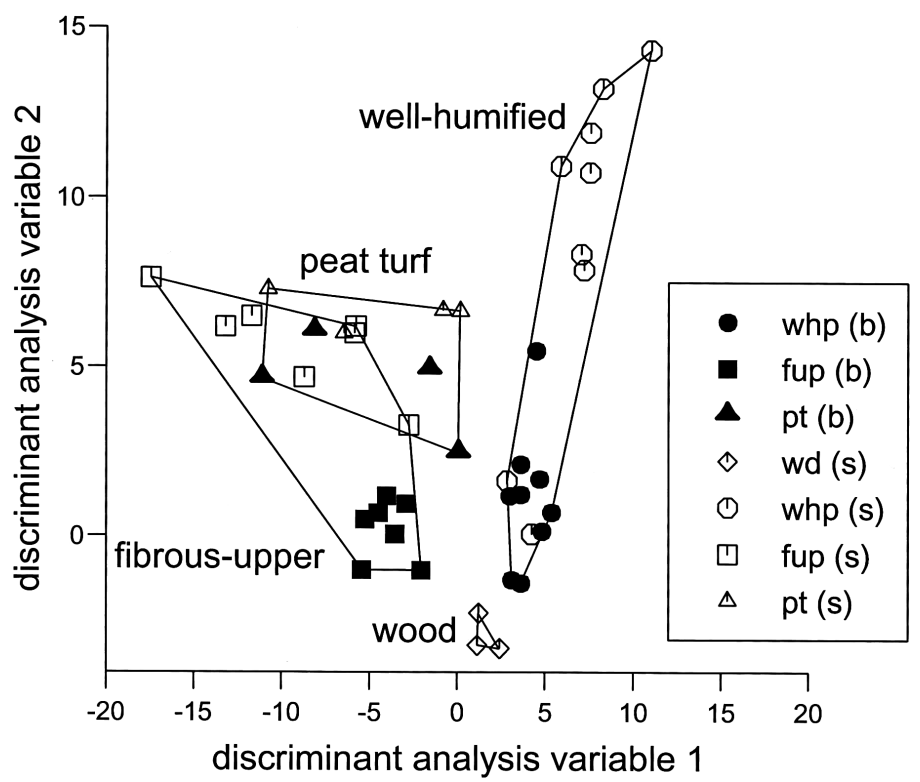

Figure 2. Room temperature discriminant biplot of magnetic measurements of experimental ash residues. Key: whp = well-humified peat; fup = fibrous-upper peat; pt = peaty turf; wd = wood; (b) = bulk sample of ash; and (s) = sieved fraction of ash $<63 \mu \mathrm{m}$ (from Peters et al., 2001; reproduced with the permission of John Wiley and Sons). 

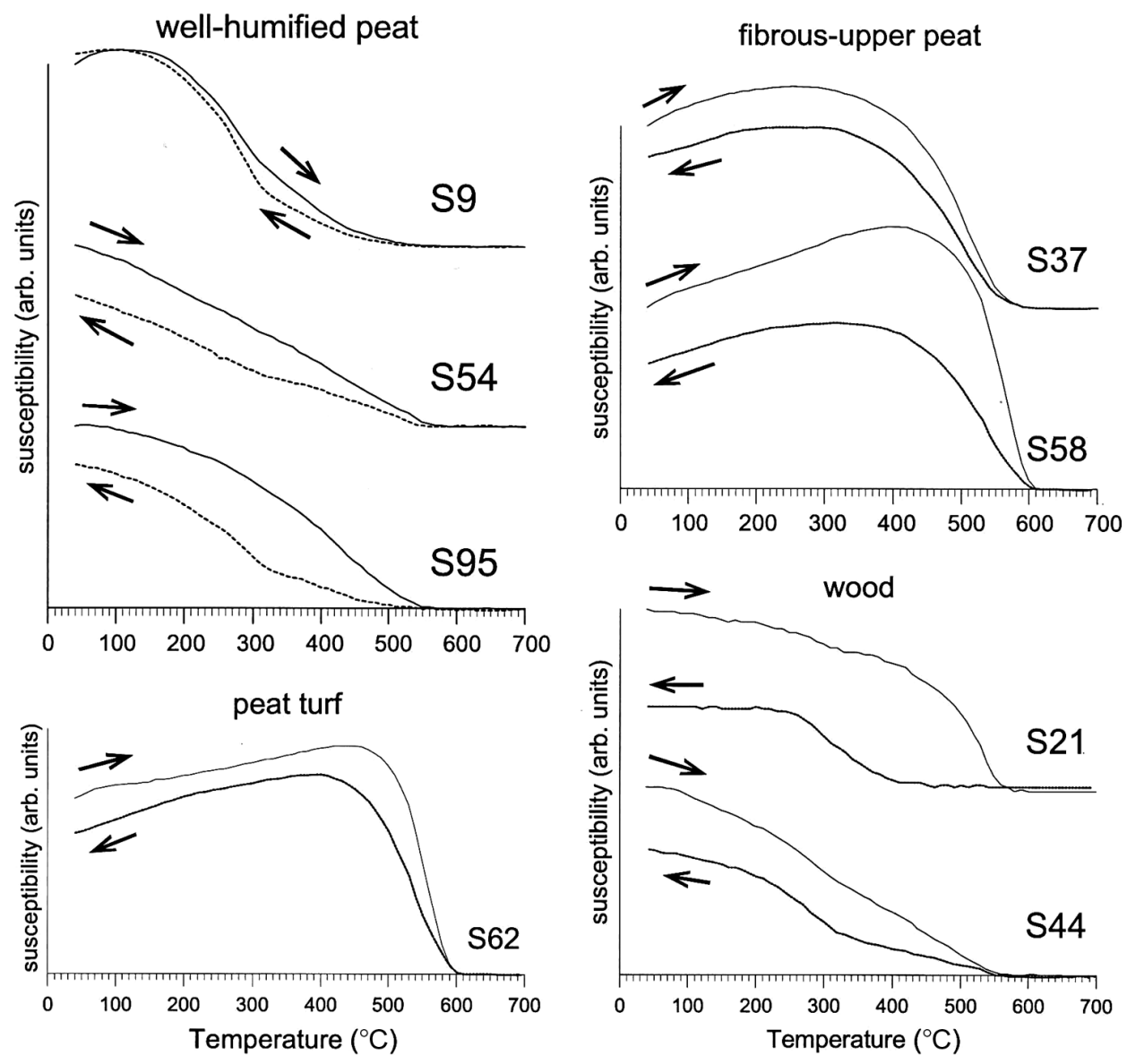

Figure 3. High temperature susceptibilities for experimental ash residues (from Peters et al., 2001; reproduced with the permission of John Wiley and Sons).

susceptibility at $\sim 600^{\circ} \mathrm{C}$, whereas the well-humified peat ash and wood ash display characteristic drops at $\sim 330^{\circ} \mathrm{C}$ and $/ \mathrm{or} \sim 550^{\circ} \mathrm{C}$ (see Figure 3). It is uncertain at present whether the observed differences relate to differences in mineralogy or domain state. The susceptibility curves could suggest mineralogy, possibly maghaemite, titanomagnetite, or modified magnetite. However, subsequent low temperature magnetic measurements carried out on the modern ash residues using a MPMS 2 SQUID magnetometer suggest the differences relate to domain state (Peters et al., 2002). For example, the samples displaying drops in susceptibility at low temperatures have a high superparamagnetic component, whereas the samples displaying drops in susceptibility at high temperatures contain a higher proportion of stable single-domain grains. The observed differences are consistent for the different fuel types, and thus measurements of archaeological ash samples can be directly compared to the results from the modern ash samples to assess fuel type (Peters et al., 2004). 


\section{Archaeobotanical Analysis from Experimental Hearths}

The bulk samples were processed using a Siraf-type wet sieve tank (Kenward et al., 1980), using 1.0 and $0.3 \mathrm{~mm}$ sieves for the flot and a $1.0 \mathrm{~mm}$ sieve net to catch the residue. The material was air-dried and both the flot and residue fully sorted under 6-20× magnification. Charcoal was only sorted from the $>4 \mathrm{~mm}$ fraction, as identification is very difficult below this size (Pearsall, 2000: 130).

All plant macrofossil identifications were checked against botanical literature (Beijerinck, 1947; Berggren, 1969; 1981; Schweingruber, 1990; Anderberg, 1994) and modern reference material from collections in geography and archaeology at the University of Edinburgh. Each seed was given a count of one, even if broken, except for those large fragments that were clearly from the same seed (following van der Veen, 1992). Other miscellaneous plant parts, such as heather leaf fragments, were given a fragment count rather than a quantifiable count, due to multiple fragmentation (following Dickson, 1994). The charcoal fragments were generally identified to genus, with the number of fragments and weight in each sample for each genus recorded. The fragments were also categorized into roundwood or timber and the number of rings noted.

\section{THE ARCHAEOLOGICAL SITES}

\section{The Archaeology of Atlantic Scotland}

The archaeology of Atlantic Scotland is a unique resource for the archaeology of the British Isles. The research potential is great not only because of the wide diversity of monuments, both in age and function, but also because of their remarkable structural and stratigraphic preservation (cf. Dun Vulan in South Uist [Parker-Pearson and Sharples, 1999], Loch na Beirgh in Lewis [Harding and Gilmour, 2000], Howe in Orkney [Ballin-Smith, 1994], Scatness in Shetland [Nicholson and Dockrill, 1998]). This preservation can be likened to mainland urban excavations, albeit on a smaller scale, and their formation and survival is the product of a complex interplay of many factors. One of these factors is the spreading of domestic refuse, including hearth material, within and beyond the confines of the structures. At most sites, the ash component originates from hearths that survive largely intact and contain residues from the final phase of use. This results in extensive ash spreads and ashy middens across the sites, for example, the external midden at Dun Vulan (Parker-Pearson and Sharples, 1999) and the material infilling features at Scatness (Dockrill et al., 2001). These deposits contain a large range of ecofacts that form the backbone of sitebased environmental and economic reconstruction.

\section{On-Site Sampling}

Mineral magnetic samples from hearths, ash spreads, and other ash-rich contexts have been analyzed from nine later prehistoric and historic sites from Lewis, South Uist, and Shetland (see Figure 1). Seven of the nine sites analyzed were excavated on Lewis as part of the wider Calanais Archaeological Research Project (Harding, 2000). 


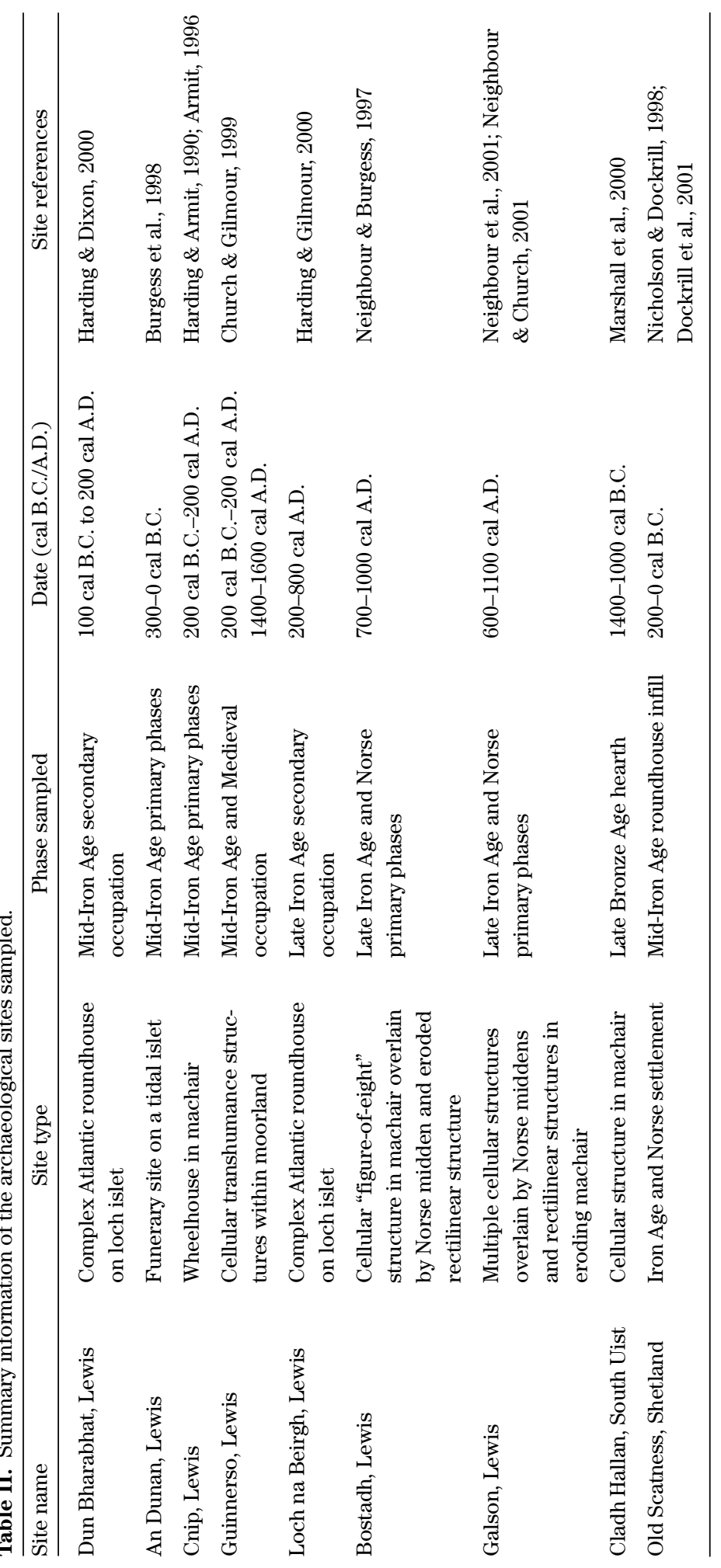


Table III. Room temperature magnetic measurements for Dun Bharabhat and Cladh Hallan.

\begin{tabular}{|c|c|c|c|c|c|c|}
\hline Sample & $\chi_{i n}$ & $\kappa_{\mathrm{fd}} \%$ & SARM & SIRM & $\mathrm{ARM}_{\text {demag40mT }} / \mathrm{SARM}$ & $\mathrm{IRM}_{60 \mathrm{mT}} / \mathrm{SIRM}$ \\
\hline \multicolumn{7}{|c|}{ Dun Bharabhat } \\
\hline C131A & 27.8 & 7 & 16 & 210.8 & 0.07 & 0.88 \\
\hline C165 & 32.8 & 6.7 & 19 & 332.1 & 0.1 & 0.75 \\
\hline $\mathrm{C} 210$ & 50.1 & 5.6 & 29.4 & 701 & 0.13 & 0.73 \\
\hline $\mathrm{C} 176 \mathrm{~b}$ & 19.4 & 6.6 & 11.7 & 224.4 & 0.18 & 0.8 \\
\hline \multicolumn{7}{|c|}{ Cladh Hallan } \\
\hline $\mathrm{S} 1$ & 0.4 & 6.6 & 0.29 & 8.02 & 0.5 & 0.42 \\
\hline $\mathrm{S} 2$ & 6.94 & 6.9 & 2.76 & 91.88 & 0.27 & 0.72 \\
\hline S3 & 9.92 & 7.3 & 3.87 & 103.9 & 0.19 & 0.73 \\
\hline S4 & 18.6 & 7.5 & 6 & 166.2 & 0.06 & 0.85 \\
\hline S5 & 41.7 & 6 & 12.4 & 443.4 & 0.08 & 0.86 \\
\hline $\mathrm{S} 6$ & 11.6 & 6.6 & 5.54 & 178 & 0.21 & 0.71 \\
\hline S7 & 8.39 & 7.4 & 3.54 & 105.5 & 0.15 & 0.73 \\
\hline $\mathrm{S} 10$ & 17.3 & 7.4 & 3.76 & 103.8 & 0.05 & 0.81 \\
\hline $\mathrm{S} 11$ & 19.1 & 7.2 & 3.86 & 114.9 & 0.07 & 0.81 \\
\hline $\mathrm{S} 12$ & 10.7 & 8.2 & 2.31 & 61.08 & 0.08 & 0.78 \\
\hline $\mathrm{S} 13$ & 44.2 & 7 & 9.72 & 342.4 & 0.04 & 0.8 \\
\hline $\mathrm{S} 14$ & 17.2 & 7.6 & 4.06 & 132.1 & 0.06 & 0.78 \\
\hline
\end{tabular}

Table II outlines the summary details of these sites and Cladh Hallan in South Uist and Old Scatness, Shetland. Most of these sites were total sampled for bulk and routine samples (Jones, 1991), meaning samples were taken from every sealed and coherent soil context uncovered. This allowed the ash from all the hearth and ash spreads from each of the sites to be sourced, using material from the routine soil samples. More detailed column sampling at $2 \mathrm{~cm}$ intervals through hearth deposits were undertaken at Guinnerso and Galson (see Peters et al., 2000, 2001), Cladh Hallan (Peters and Batt, 2002), and Old Scatness (Dewar et al., 2002). Only hearth material and ash spreads were analyzed using the detailed mineral magnetic work described above, as past research has shown that these contexts allowed more coherent interpretation than mixed deposits, such as floor levels and middens. These latter context types were more likely to contain other magnetic material of unknown origin, possibly of a bacterial magnetosome component (Peters et al., 2000, 2001).

\section{Mineral Magnetic Measurements for Archaeological Samples}

The six room-temperature measurements described in Section 3 (susceptibilities, ARMs, and IRMs) were measured for the archaeological samples of ash-rich contexts, sieved to $63 \mu \mathrm{m}$. The measurements from two sites, Dun Bharabhat and Cladh Hallan, are shown in Table III as an example of the basic data. The range of results from the other sites is shown in Table I. High temperature susceptibilities were also monitored for representative samples from each site. 
Table IV. Summary information of the experimental fire hearth cycles.

\begin{tabular}{llll}
\hline $\begin{array}{l}\text { Fire hearth } \\
\text { cycle }\end{array}$ & \multicolumn{1}{c}{ Fuel type } & \multicolumn{1}{c}{ Volume of ash (litres) } & \multicolumn{1}{c}{ Ash Munsell color } \\
\hline FH1 & Well-humified peat & 14 & 5YR 7/8 Reddish yellow \\
FH2 & Fibrous upper peat & 28 & 10R 4/8 Red \\
& & & 10R 6/1 Reddish gray \\
FH3 & Wood & 3 (largely charcoal) & GLEY 2 7/1 Light bluish gray \\
& & & GLEY 2 5/1 Bluish gray \\
FH4 & Well-humified peat & 11 & 5YR 7/8 Reddish yellow \\
FH5 & Fibrous upper peat & 14 & 10R 4/8 Red \\
FH6 & Wood & 3 (largely charcoal) & GLEY 2 7/1 Light bluish gray \\
& & & GLEY 2 5/1 Bluish gray \\
FH7 & Well-humified peat & 11 & 5 YR 7/8 Reddish yellow \\
FH8 & Fibrous upper peat & 14 & 10R 4/8 Red \\
FH9 & Peaty turf & 21 & 2.5 YR 4/6 Red \\
FH10 & Well-humified peat & 7 & $5 Y R ~ 7 / 8$ Reddish yellow \\
FH11 & Fibrous upper peat & 17 & 10YR 4/8 Red \\
FH12 & Wood & 2 (largely charcoal) & GLEY 2 7/1 Light bluish gray \\
FH13 & Well-humified peat & 7 (covered with sand for a week) & 5YR 7/8 Reddish yellow \\
FH14 & Peaty turf & 14 (covered with sand for a week) & 10R 4/8 Red \\
FH15 & Fibrous upper peat & 7 (covered with sand for a week) & 10 YR 4/8 Red \\
FH16 & Well-humified peat & 3 (covered with sand for a year) & $5 Y R$ 5/8 Yellowish red \\
FH17 & Peaty turf & 3 (covered with sand for a year) & 2.5 YR 4/6 Red \\
FH18 & Fibrous upper peat & 4 (covered with sand for a year) & 10 YR 4/8 Red \\
\hline
\end{tabular}

\section{RESULTS}

\section{General Observations from Experimentation}

Table IV presents the Munsell colors and the volumes of the ash produced by each of the fire hearths. It can be seen that each fuel type created a certain color range of ash, with the well-humified peat producing reddish yellow ash, whereas the fibrousupper peat and peaty turf produced ash of a much darker red color. The ash from wood was much lighter in color, ranging from gray to white. Superficially, this may suggest that the color of archaeological ash could be the first clue to the fuel source, but caution must be exercised in using this approach as the color is as likely to be governed by the atmospheric conditions during the burning and post-deposition processes as the fuel source (Carter, 1998, 1999). Of more archaeological relevance is the difference in ash volume produced by the fuel sources. The amount of fuel put onto each fire was not recorded and the volume measurements take no account of compaction differences, so accurate differences are hard to quantify. However, it is obvious from the volume measurements and observation during the burning that the peat and turf produced significantly more ash than the wood. Indeed, despite burning at least a young pine tree on each wood fire, very little ash was left. Conversely, the peat fires were generally overflowing with ash at the end of the 72 hours. This has important implications for Atlantic Scottish archaeology. For example, the large volume of ash that would have been produced from the continuous 
burning of peat fires would create a large amount of material that could accumulate and be curated throughout the settlement. The spread of ash would therefore be an important contributor to archaeological stratigraphy, trapping artifacts and ecofacts for recovery thousands of years later. Extensive ash spreads form an important group of samples within this study, and almost every later prehistoric domestic site in the region has significant ash components within the recorded stratigraphy. These peat ash spreads are easily observed and sampled on the sites, but ash from wood would be very difficult to spot without detailed soil micromorphology, due to the much smaller volume produced from similar burning periods.

\section{Mineral Magnetic Results}

Figure 4 displays the discriminant biplots of the room temperature measurements for the hearth and ash spread samples from the seven sites from Lewis. These are displayed in approximate chronological order from Dun Bharabhat (Mid-Iron Age) to Guinnerso (Late Medieval). The samples are displayed as one assemblage for four of the sites, as the measurements were taken from the same general period (i.e., Mid-Iron Age, Late Iron Age). Differentiation is made between the Late Iron Age and Norse samples from Galson, and the Iron Age and Late Medieval samples from Guinnerso. More detailed discussion on the implications for the sites are presented within the individual site reports (for example Church and Peters, 2000).

In general, most of the samples from the sites are grouped around the wellhumified envelope within the biplot. This consistent pattern is confirmed by the high temperature susceptibility measurements, with representative samples displayed in Figure 5. For example, the three measurements from Bostadh, Galson, and Guinnerso are consistent with the experimental profiles from well-humified peat (see Figure 3), with the susceptibility approaching zero by $\sim 550-560^{\circ} \mathrm{C}$. Conversely, the susceptibility approaches zero at $\sim 600-610^{\circ} \mathrm{C}$ for the sample from Dun Bharabhat, one of the few that recorded this profile from the sites in Lewis (Church and Peters, 2000). This sample also trends toward the peaty turf envelope in the room temperature biplot, representing a probable mix of well-humified and peaty turf confirmed by the plant macrofossil record (Church, 2002b).

Overall, little change is observed over time, though slight variation can be seen from site to site in terms of their position within the biplot. For example, some samples from the three sites on the Bhaltos Peninsula (Dun Bharabhat, Cnip, and Loch na Beirgh) plot to the right of the well-humified envelope (see Section 6.1 below). The other biplot of note is the Late Iron Age samples from Galson that have elements of peaty turf and wood within the assemblage, supported by the associated archaeobotanical assemblages, though the main fuel source is again well-humified peat.

Figures 6 and 7 display the discriminant biplots of the room-temperature measurements for Cladh Hallan and Scatness. Differentiation is made between the upper and lower levels of the hearth profile in Cladh Hallan, which correspond to different floor levels within the house sequence. Both the biplots differ from the general pattern at the Lewis sites, with more diversity in the discrimination. The lower hearth 


\section{CHURCH ET AL.}
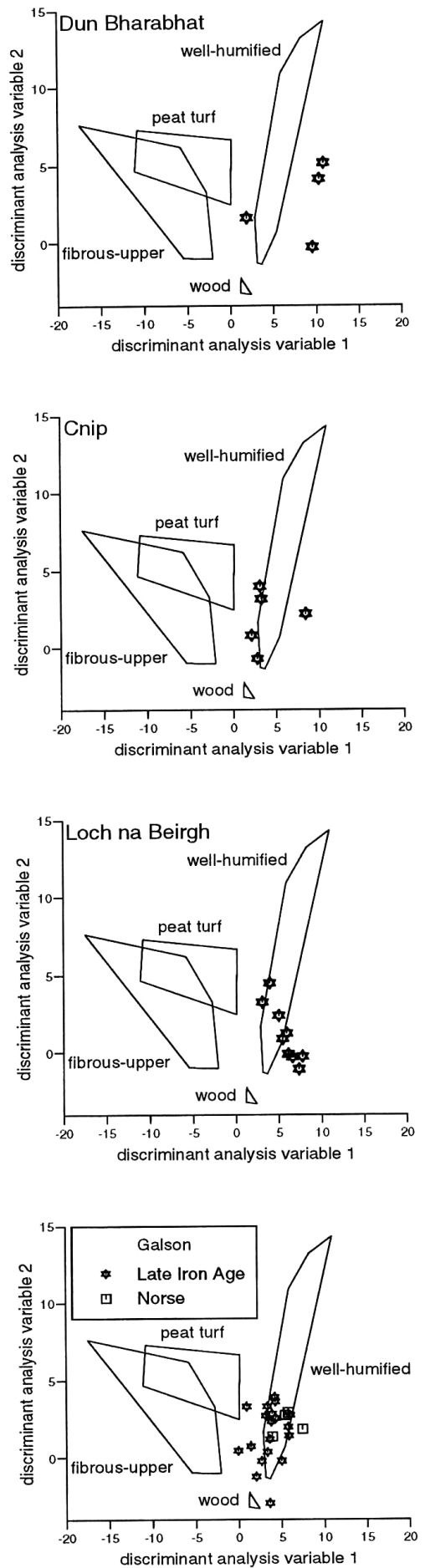
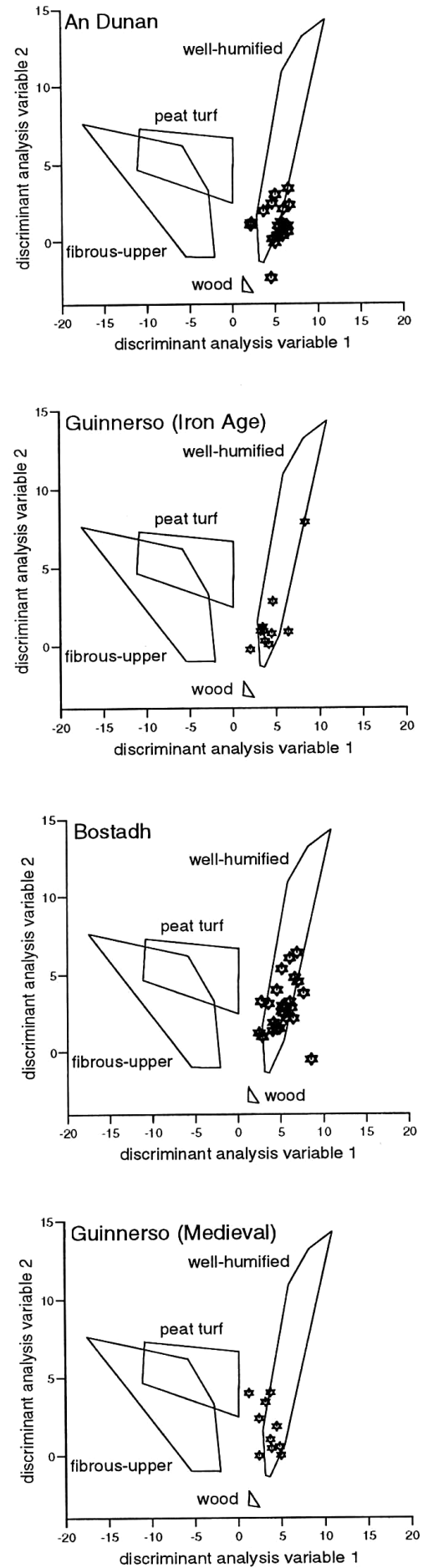

Figure 4. Discriminant biplots for sites from Lewis. 

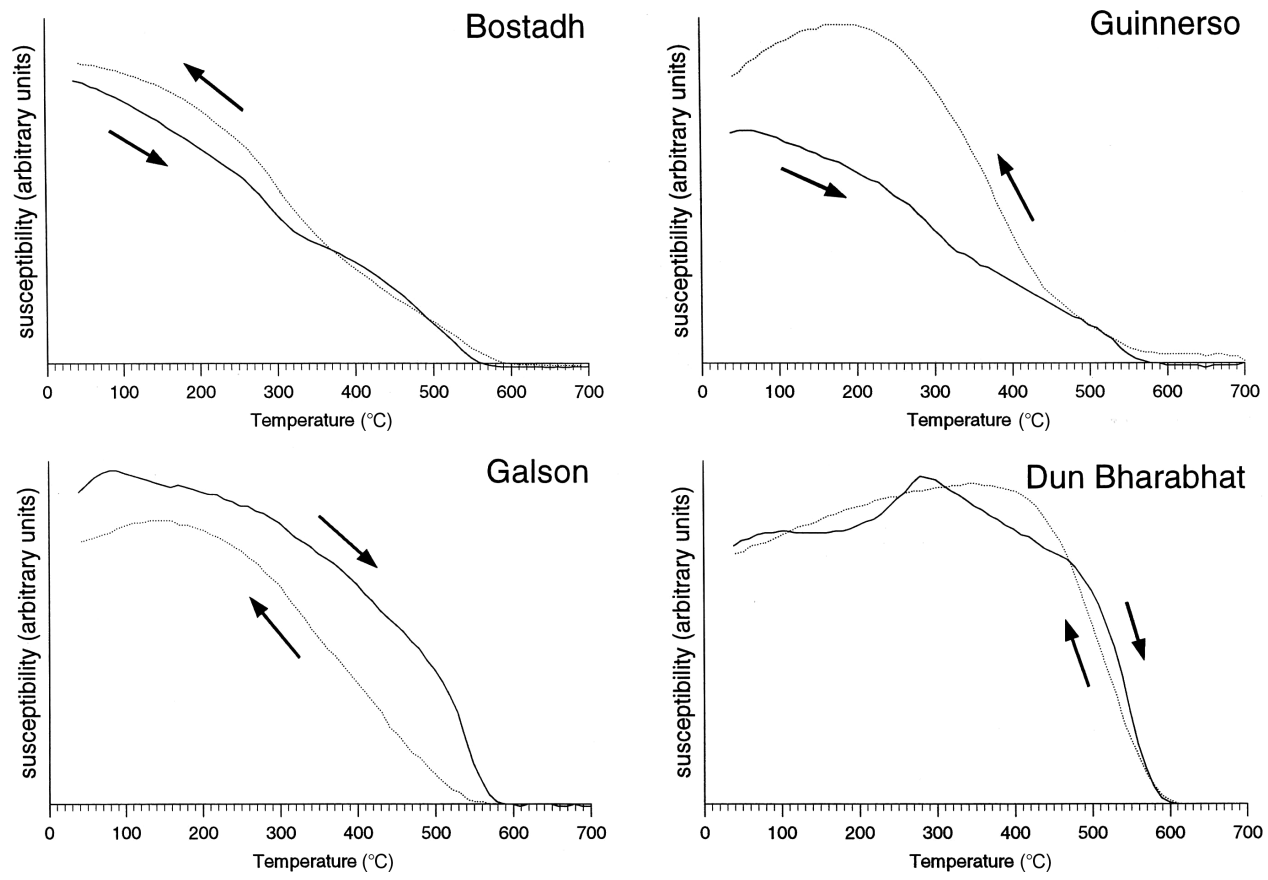

Figure 5. High temperature susceptibility measurements of representative samples for sites from Lewis.

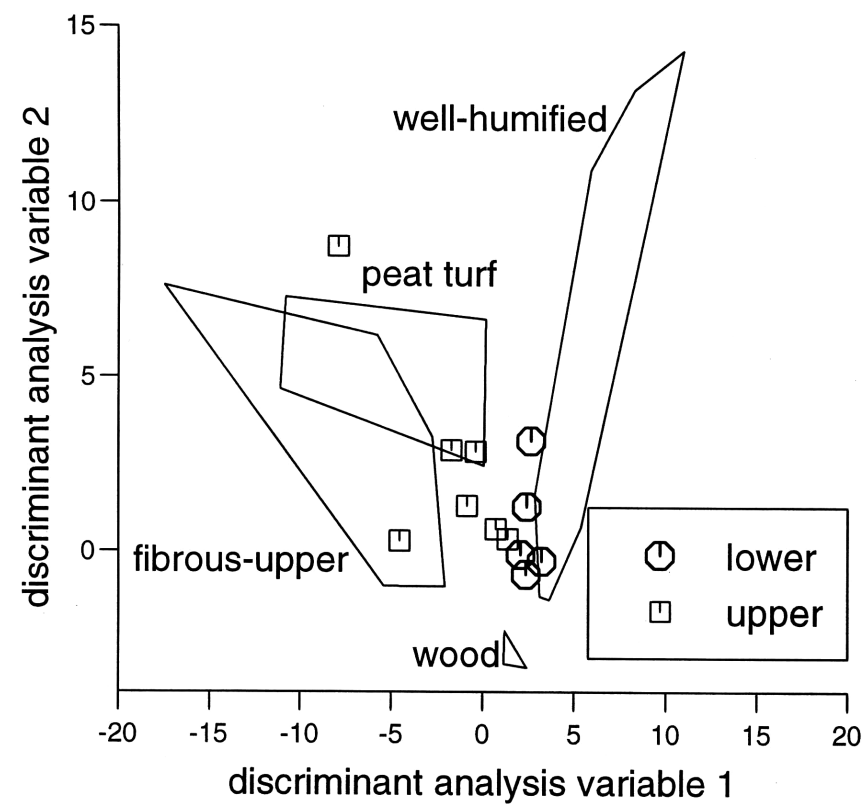

Figure 6. Discriminant biplot for Cladh Hallan (upper and lower relate to levels in the sampled hearth ash). 


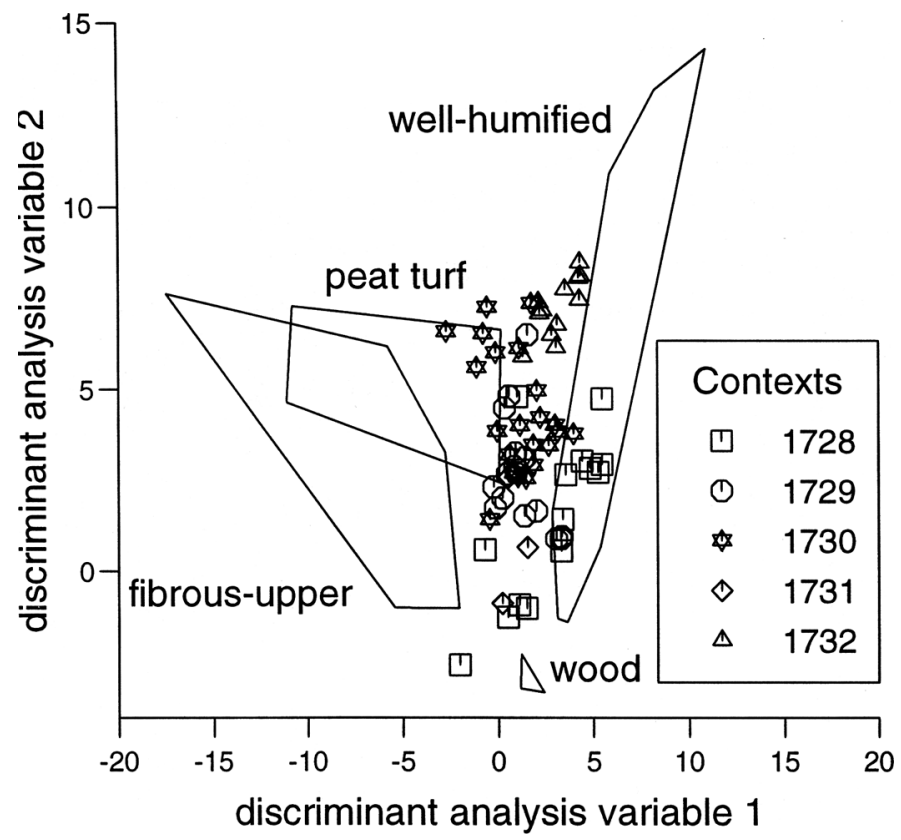

Figure 7. Discriminant biplot for Old Scatness.

samples from Cladh Hallan cluster around the well-humified peat envelope, confirmed by the high temperature susceptibility curve in the top left of Figure 8. However, the upper hearth samples trend and cluster toward the peaty turf and fibrous-upper peat on the biplot, which is again confirmed by the high temperature susceptibility curve in the bottom left of Figure 8. Hence, these two phases of repeated episodes of burning show two different fuel procurement strategies operating within the same overall time period, possibly related to a change in the availability of one fuel type.

This pattern of diversity is also shown by the samples from Scatness, with ashy material displaying variation in both the room-temperature biplot (Figure 7) and the high temperature susceptibilities (Figure 8). The biplot shows that samples from three archaeological contexts (1730, 1731, and 1732) display similar mixed groupings and that there is considerable variation between these contexts and the others. This would imply that different fuel sources, or combinations of fuel sources, contribute to each distinct archaeological context. The grouping of samples from some of these contexts also supports the archaeological interpretation of minimal mixing between the stratigraphic units. Whether this relates to variations in the fuel source type or other effects is discussed later. The high temperature susceptibilities show distinctly different behavior from that of the samples at other sites, with a higher Curie temperature and lower susceptibility following laboratory reheating, which may be attributed to high temperature heating of the deposits in the past. 

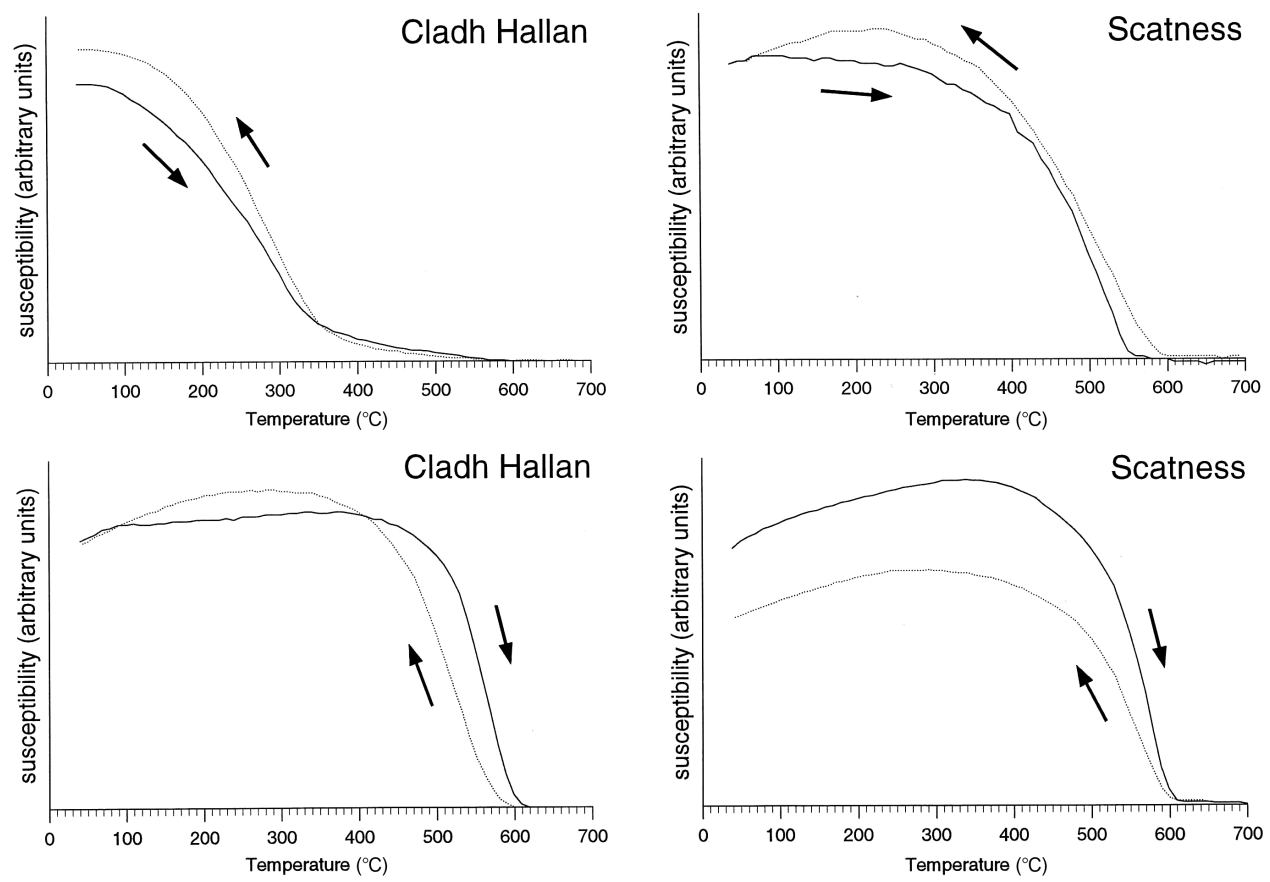

Figure 8. High temperature susceptibility measurements of representative samples for sites from Cladh Hallan and Old Scatness.

\section{Archaeobotanical Results}

Table V presents the archaeobotanical results from representative bulk samples from the experimental program. The first key observation is that all human behavioral episodes involving input of plant material into the fire have left some form of remains relating to the activity. Every sample contained variable concentrations of the lichen (Ramalina sp.) and most samples had pinewood (Pinus sp.), both of which were used as kindling to start the fire. Each fuel type had a specific suite of plant material of variable concentrations within it.

Turning first to the charcoal, unsurprisingly the most common type was pine timber from the wood chippings, though pine roundwood was also recovered. Birch (Betula sp.) timber and roundwood fragments were also discovered in Dumps 1 and 3 as well as a single fragment of Ling heather roundwood (Calluna vulgaris L.). Most of the fragments came from the well-humified peat dump, and as fuel input into the fire hearths was carefully controlled, it seems likely that the birch and heather were introduced from the peat. Clearly, this has important implications for charcoal recovered from archaeological sites in Atlantic Scotland, as some of the fragments, especially birch, could have been introduced with the fuel source rather than from any direct use by the people around the hearth. Indeed, this is further evidence for the dangers of using charcoal as a dating medium in Atlantic Scotland, because the birch will be approximately the same age as the peat (cf. Ashmore 1999; Church, 2002b). 


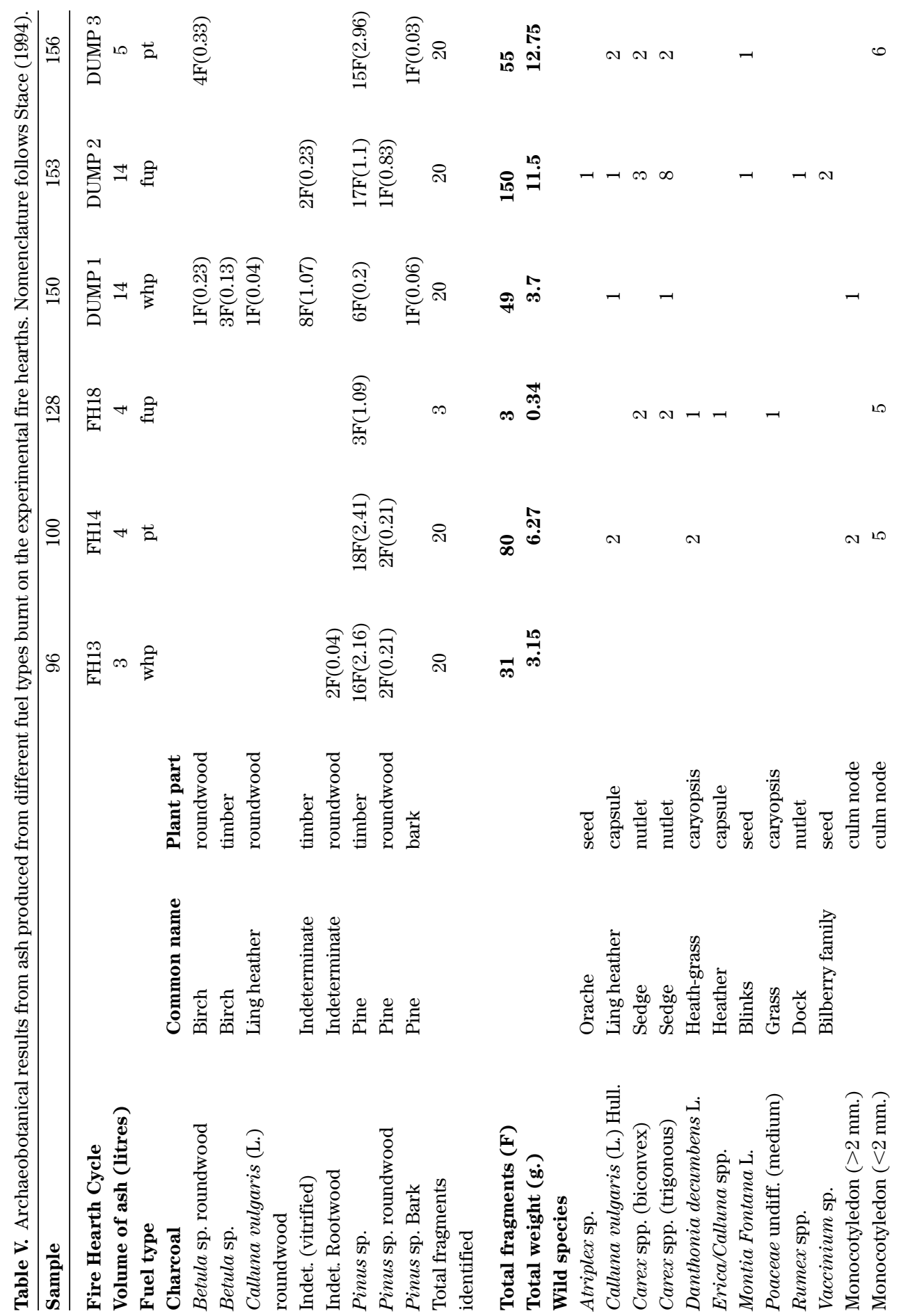




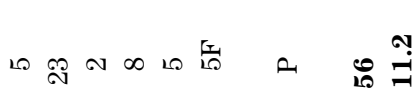

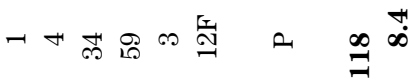

$$
\begin{aligned}
& H-T \text { a } \\
& \infty 8 \underset{\exists}{ } \text { ค }
\end{aligned}
$$

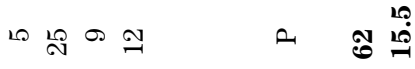

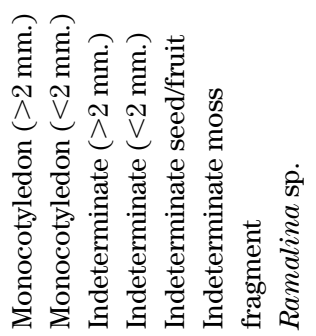

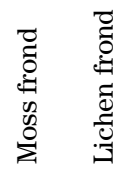


Clear differences have emerged from the different fuel types. The first difference involves the appearance and character of the burnt amorphous peat fragments between the well-humified peat and the fibrous-upper peat and peaty turf. Wellhumified peat produces an amorphous peat with no obvious structure, whereas the other two types produce peat with obvious structural elements, such as specific layers of poorly humified fibrous material. These differences would be easily spotted from the burnt peat fragments in the archaeological record. The second difference involves the comparison of macrofossil concentration (Quantifiable Components/liter) between each of the types. Well-humified peat has very low concentrations (1.0 from FH13 and 0.6 from Dump 1), whereas fibrous-upper peat and peaty turf have much higher concentrations, ranging from 8.4 to $65 \mathrm{QC} /$ liter. The few macrofossils recovered from the well-humified peat samples include indeterminate rhizomes, small culm bases and single seeds of Ling and sedge (Carex sp.). However, the fibrous-upper peat and peaty turf contain far greater numbers of culm nodes/bases and rhizomes, most of which are less than $2 \mathrm{~mm}$ in diameter. Both fibrous-upper peat and peaty turf also have a greater number of seeds from acid-loving plants present on the heath from where the shallow peat and turf was cut. The carbonized seeds from these plants include heather, sedges, oraches (Atriplex sp.), heath grass (Danthonia decumbens L.), undifferentiated grass (Poaceae), dock (Rumex sp.), Blinks (Montia fontana L.), and even a couple of seeds from the Bilberry family (Vaccinium sp.). Fruits from the Bilberry family could have provided gathered food in the past, so the possibility of fuel contamination must be considered when interpreting archaeological seeds from this family.

\section{DISCUSSION}

\section{Magnetic Variation}

It has been suggested that the uniformity and variation in the magnetic signatures of the ash-rich samples are generally a reflection of the fuel source that produced the ash. However, there are a number of possible other effects that could create the variation observed.

First, the variation may relate to other fuel sources not part of the experimentation to this point. These include seaweed, dung, straw/hay, other types of organic turf, and other types of wood. However, nearly all of these fuel types leave recognizable macrofossils in the archaeobotanical assemblages, few of which have been recovered from the Lewis sites. Post-excavation is still ongoing at Cladh Hallan and Scatness, and evidence of these other fuel sources will be looked for in the associated archaeobotanical assemblages. Past research by McClean and Kean (1993) has also shown that little magnetic variation occurs through the burning of different wood types.

Second, the underlying solid and drift geology from where the peat or turf was cut could introduce magnetic particles leading to the variation. Hints that the geology may be a factor in magnetic variation stem from the consistent plot to the right of the well-humified envelope in the room temperature biplots of samples from the three sites from the Bhaltos Peninsula in Lewis. Also, a sequence of samples taken through a Late Iron Age hearth at Galson displayed two similar, but slightly different, high 
temperature susceptibilities, both indicating well-humified peat (Figure 8 in Peters et al., 2000). The room-temperature biplots from this hearth are also consistent with the well-humified peat identification, and the slight variation in high temperature susceptibilities has been interpreted as different sources of peat with different underlying drift geology. However, a number of specific magnetic susceptibility $\left(\chi_{i n}\right)$ profiles through "natural" peat and turf sections in Lewis have demonstrated only a very slight magnetic enhancement through the C-horizon, subsoil, and underlying drift geology (Church and Peters, 2004). Also, much of the Western Isles is underlain by Lewisian Gneisses (Gribble, 1994) that are relatively inert magnetically. However, the same cannot be said for Shetland, which has one of the most complex solid and drift geologies of the Scottish islands (Turner, 1998). This may explain the wide variation displayed by the samples from Scatness.

Third, the pre-burning and post-depositional history of the fuel and its ash could affect its magnetic properties. For example, from the ethnographic evidence of Shetlands recent past (Fenton, 1978), turf was commonly used as a flooring material in a byre or building, as well as roofing material, before burning, and there is anecdotal evidence of the charring and quenching of fibrous-upper peat before its use in iron working, to improve its properties as a fuel (Dewar et al., 2002). Post-depositional processes and pedogenesis of archaeological deposits could also alter the magnetic properties of the samples. For example, floor levels and middens from Galson and Guinnerso displayed evidence of a possible bacterial magnetosome component in the samples (Peters et al., 2000, 2001). This was attributed to the higher levels of organic material within the floor levels and middens compared to the less organic, ash-rich samples chosen for this analysis. More obvious pedogenic processes are more easily identified on-site. For example, both podzolization and iron-pan formation were observed in the Early Iron Age site of Gob Eirer in Lewis (Church et al., 1999), which, despite having evidence of burnt well-humified peat plant macrofossils throughout the site, displayed only significant magnetic enhancement in 5 of the 50 samples. The post-depositional processes, coupled with waterlogging and leaching, explain the flushing out of the majority of the magnetic particles from the site stratigraphy.

Fourth, the input of magnetic material from sources other than the fuel is another possible factor in the variation. Processes such as metalworking introduce highly magnetic material into the surrounding contexts and associated dumps (Sim, 1998). The choice of hearth material and ash spreads reduced the potential for such input, compared to floor levels and middens, and the use of sieved material less than $63 \mu \mathrm{m}$ will have removed many of these other magnetic particles, such as slag spheres and hammerscale, from the metalworking process (Englike, 1991).

The final factor in the variation is mixing of the fuel sources themselves. To this point, the analysis is underpinned with the assumption that the ash results from the burning of a predominant fuel type in a single burning episode, supported by ethnographic observations from the recent past (Martin, 1716; Fenton, 1978). However, this was not necessarily the case in prehistory. Therefore, a series of low temperature remanences have been measured using a $\mathrm{MPMS}_{2}$ squid magnetometer for the experimental samples. A quantitative unmixing algorithm was successfully developed to 
quantify fuel ash mixing for the few archaeological samples measured so far (Peters et al., 2002).

In summary, the authors feel that the factors outlined above are relatively insignificant for the samples from Lewis and Cladh Hallan in South Uist. However, the variation exhibited by the samples from Scatness may well relate to some of these factors, such as the underlying geology, as well as the variation in fuel source, so caution should be exercised for interpretation from this site.

\section{Archaeological Implications}

It has been argued that the results from the seven Lewis sites demonstrate that well-humified peat was the dominant fuel source from each site. The uniformity of fuel source spans a period from the Mid-Iron Age to the end of the Medieval from sites with a wide diversity of functions, indicating that the procurement of well-humified peat from the large tracts of inland blanket bog has been an important component of the local economy for thousands of years. This hints at a degree of management for the peat banks that would have been visible in the landscape, including issues of territoriality and ownership. For example, the recurring magnetic signal from some of the well-humified peat samples from the three sites in the Bhaltos Peninsula perhaps indicates a localized source, though further experimentation would be needed to investigate any magnetic variability of different tracts of well-humified peat. It can be suggested that this evidence may indicate possible co-operation between the inhabitants of the sites in terms of resource procurement, perhaps involving communal effort in the peat cutting, drying, and gathering over the spring and summer. It also implies a long-term stability in the division and tenure of the peatlands, as occupation of the three sites overlap and spans over half a millennium.

The few differences in fuel source from the sites in Lewis include limited use of peaty turf and fibrous-upper peat from Dun Bharabhat and Galson and some evidence of heather burning at Guinnerso (Peters et al., 2001). This may represent intermittent burning rather than the sustained and deliberate management of these fuel types. Indeed, they may have been cut and gathered at the same time as the well-humified peat, as fibrous-upper peat, peaty turf, and heather are minor by-products from peat cutting in an area of blanket bog. From the associated archaeological evidence, none of the contexts from which the samples were taken indicated specific functional use, for example, ash from any metalworking process.

The importance of the moorland and blanket bog to the people of Lewis over thousands of years is also beginning to emerge from other archaeological evidence. Archaeobotanical evidence for the burning of well-humified peat as a fuel and the gathering of plants, such as heather, bracken, sedges, and berried plants, has been recovered from almost every domestic site sampled (cf. Church, 2002a). The excavation of the small sheiling-type structures at Guinnerso has demonstrated summer occupation of the blanket bog for specific economic and industrial activities, such as transhumance and pottery manufacture. Also, there is some evidence for the importance of the blanket bog within the belief systems of the various inhabitants of the sites. For example, the monumental hearth at the center of the funerary site of 
An Dunan contained many layers of ash, some containing cremated human bone. The mineral magnetic analysis, supported by soil micromorphology and archaeobotanical remains, demonstrated that well-humified peat was burnt to cremate the humans (see Figure 4). Also, well-humified blanket bog peat was used to create a level surface or foundation on which the Cellular phase at Loch na Beirgh was built (Harding and Gilmour, 2000). The nearest extensive source for this would have been a couple of kilometers away on the Uig Peninsula and so would have required a substantial investment of labor to cut, dry, and transport. This foundation layer for a new settlement may represent a conscious effort to forge a physical and metaphoric link from the domestic core to the hinterland moorland zone (cf. Hodder, 1990).

The samples from Cladh Hallan show a greater diversity of fuel source and a change in use over time, with well-humified peat represented in the lower levels, and peaty turf and fibrous-upper peat in the upper portion of the hearth (Peters and Batt, 2002). This diversity may reflect the position of the site within the extensive machair plain of South Uist, with the nearest source of deep well-humified peat a few kilometers from the site. Indeed, the machair and the tracts of moorland are separated by an interface zone of thin acid-neutral soils, known in South Uist as the "blackland" (Gilbertson et al., 1996). This area would have had areas of organic-rich turf and fibrous peat similar to the material used in the experimentation, which could have been stripped for fuel. Again, the gathering and transport of this material would have required a significant investment of labor and may have lead to soil erosion within the stripped areas (cf. Grattan et al., 1996). Exploitation of the "blackland" has been established for another multi-period Iron Age site within the machair (Dun Vulan: Parker-Pearson and Sharples, 1999), where the barley crop could have been grown in this interface zone, again kilometers from the site (Smith, 1999). This reinforces the picture of regional diversity, in terms of resource procurement, that is beginning to emerge between the northern and southern islands of the Western Isles chain. However, more samples on both an inter- and intra-site level are needed from the sites excavated under the Sheffield University Archaeological Research Campaign in the Outer Hebrides (SEARCH) project in order to assess this diversity in more detail.

The picture from Scatness is again one of diversity. The authors believe the variation in the biplot and high temperature profiles indicate individual samples of wellhumified and fibrous peat as well as peaty turf (though a number of other effects outlined above could have created this pattern of diversity). There is also evidence of mixed ash from the three fuel types. The grouping of samples within some contexts and the differentiation in properties between these contexts and the others implies that different combinations of fuel sources are represented. One possible interpretation is that different fuels are being selected for different purposes. Also, the resulting ash may spread from different archaeological contexts, for example, domestic hearths compared to structures devoted to industrial activities. The volume of ash deposited within the single structure (approximately $130 \mathrm{~m}^{2}$ ) over the relatively brief period of time indicated by the radiocarbon dates and lack of mixing suggests a larger scale process than the deposition of domestic fuel residues. Preliminary investigations have noted the marked similarity in magnetic properties between some of the deposits within Structure 12 and ash residues produced by experimental 
iron smelting on the site (Dewar et al., 2002), and this topic merits further investigation. Although there are no present-day peat deposits close to the site, environmental evidence suggests that the climate may have been more conducive to peat formation 2000 years ago (Turner, 1998: 8-10). Fuel depletion due to overworking is another possible explanation for the absence of peat at the site today.

The proposed variation in fuel procurement strategies also has implications for the societal systems operating across Atlantic Scotland. The long-term dependency on well-humified peat that seems to have existed in Lewis for thousands of years may have led to stable land divisions within the blanket bog interior, suggested by the consistent magnetic signature from the sites in the Bhaltos Peninsula outlined above. Conversely, the greater variation in fuel use and gathering from Cladh Hallan and Scatness may have led to a more fluid arrangement of land ownership within the marginal areas containing the fuel sources. Local trade or exchange systems in different fuel sources may have also been established for settlements without access to extensive areas of marginal land. Analysis of ash from more sites of various ages across the region is needed to establish definite trends in terms of spatial, chronological, and functional variation of fuel use.

The variation in fuel types used in different areas also has implications in terms of residuality of plant remains from the fuel source. The experimental results presented in this paper and other research have shown that different fuel types produce varying numbers and proportions of plant parts and species (McLaughlin, 1980; Dickson, 1994, 1998; Dickson and Dickson, 2000). In summary, peaty turf usually produces relatively large quantities of small culm bases and rhizome fragments, fibrous burnt peat, and some seeds of the heathers (Ericaceae undiff.), grasses (Poaceae undiff.), and the sedges (Carex spp.). However, well-humified peat produces relatively large quantities of a much more amorphous burnt peat and very few residual plant macrofossils, usually consisting of rhizome fragments. Therefore, sites that have well-humified peat as their dominant fuel source will have little in the way of contamination, apart from amorphous burnt peat and specific types of rhizome that can be easily identified. Sites that have more mixed fuel sources, especially turf, will have much greater problems with contamination. Hence, it can be proposed that the archaeobotanical assemblages from the Lewis sites will have less contamination from the fuel sources than the other two sites investigated.

\section{CONCLUSIONS}

1. The application of the technique developed by Peters et al. (2001, 2002, 2004) is successful for ash samples from a number of sites in Atlantic Scotland, demonstrating both uniformity and diversity in fuel use.

2. There is a marked continuity of practice in fuel procurement in the later prehistoric and historic periods in Lewis, with well-humified peat the dominant fuel source. This would have required a degree of management for the peat banks, including issues of territoriality and ownership. It also implies a long-term stability in the division and tenure of the peatlands, possibly over thousands of years. 
3. Greater variation in fuel procurement from Cladh Hallan, South Uist, and Scatness, Shetland, may reflect different procurement and land management patterns on these islands and the selection of various fuels for different functions.

4. The variation in fuel types used in different areas has implications in terms of residuality of plant remains from the fuel source within archaeobotanical assemblages recovered from the sites. It is proposed that the archaeobotanical assemblages from the sites in Lewis will have less contamination from the fuel sources than the other two sites investigated.

The authors would like to thank Geraint Coles and Ian Lawson for comments on an earlier draft. Ian Armit is thanked for permission to use and amend Figure 1, illustrated by Kevin Hicks. John Wiley and Sons are thanked for permission to reproduce Figures 2 and 3 from Peters et al., 2001a. We would also like to thank the directors of the various excavations, including Dennis Harding, Simon Gilmour, Ian Armit, and Tim Neighbour for access to the Lewis material; Steve Dockrill at Old Scatness; and Mike Parker Pearson and Helen Smith for access to the Cladh Hallan hearth samples. The work was supported by a Caledonian Research Foundation Scholarship to MC and a British Petroleum/Royal Society of Edinburgh Research Fellowship to CP.

\section{REFERENCES}

Anderberg, A.-L. (1994). Atlas of seeds: Part 4, Resedaceae-Umbelliferae. Stockholm: Swedish Museum of Natural History.

Anderson, S., \& Ertug-Yaras, F. (1998). Fuel, fodder and faeces: An ethnographic and botanical study of dung fuel use in Central Anatolia. Environmental Archaeology, 1, 99-109.

Armit, I. (1996). The archaeology of Skye and the Western Isles. Edinburgh: Edinburgh University Press.

Ashmore, P.J. (1999). Radiocarbon dating: Avoiding errors by avoiding mixed samples. Antiquity, 73, 124-130.

Ballin-Smith, B. (Ed.) (1994). Howe: Four millennia of Orkney prehistory. Society of Antiquaries of Scotland Monograph Series No. 9. Edinburgh: Society of Antiquaries of Scotland.

Batt, C.M., \& Dockrill, S.J. (1998). Magnetic moments in prehistory: Integrating magnetic measurements with other archaeological data from Scatness multiperiod settlement. Archaeological Prospection, 5, $217-228$.

Beijerinck, W. (1947). Zadenatlas der Nederlandsche flora. Wageningen: Veenman.

Bellomo, R.V. (1993). A methodological approach to identifying archaeological evidence of fire resulting from human activities. Journal of Archaeological Science, 17, 1-11.

Berggren, G. (1969). Atlas of seeds, Part 2, Cyperaceae. Stockholm: Swedish Museum of Natural History.

Berggren, G. (1981). Atlas of seeds, Part 3, Salicaceae-Cruciferae. Stockholm: Swedish Museum of Natural History.

Birks, H.J.B. (1994). Floristic and vegetational history of the Outer Hebrides. In R.J. Pankhurst \& J.M. Mullin (Eds.), Flora of the outer hebrides (pp. 32-38). London: HMSO.

Boardman, S.J. (1995). Charcoal and charred macrofossils. In K. Branigan \& P. Foster (Eds.), Barra: Archaeological research on Ben Tangaval (pp. 149-157). Sheffield: Sheffield Academic Press.

Bond, J. (1998). Beyond the fringe? Recognising change and adaptation in Pictish and Norse Orkney. In C. Milles \& G.M. Coles (Eds.), Life on the edge: Settlement in marginal areas (pp. 81-90). Oxford: Oxbow.

Bottema, S. (1984). The composition of modern charred seed assemblages. In W. van Zeist \& W.A. Casparie (Eds.), Plants and ancient man (pp. 207-212). Rotterdam: Balkema.j+28

Brayshay, B.A., \& Edwards, K.J. (1996). Lateglacial and Holocene vegetational history of South Uist and Barra. In D.D. Gilbertson, M. Kent, \& J.P. Grattan (Eds.), The Outer Hebrides: The last 14,000 years (pp. 13-26). Sheffield: Sheffield Academic Press.

Burgess, C., Church, M.J., Flitcroft, C., \& Gilmour, S.M.D. (1998). An Dunan, Uig Parish. Discovery and Excavation in Scotland (1997), 85. 


\section{CHURCH ET AL.}

Canti, M.G., \& Linford, N. (2000). The effects of fire on archaeological soils and sediments: Temperature and colour relationships. Proceedings of the Prehistoric Society, 66, 385-395.

Carter, S. (1998). The use of peat and other organic sediments as fuel in northern Scotland: Identifications derived from soil thin sections. In C. Milles \& G.M. Coles (Eds.), Life on the edge: Settlement in marginal areas (pp. 99-104). Oxford: Oxbow.

Carter, S. (1999). Soil micromorphology. In C. Lowe, St. Boniface Church, Orkney: Coastal erosion and archaeological assessment (pp. 172-186). Stroud: Sutton Publishing.

Charles, M. (1998). Fodder from dung: The recognition and interpretation of dung-derived plant material from archaeological sites. Environmental Archaeology, 1, 111-121.

Church, M.J. (2002a). Plants and people in the later prehistoric and Norse periods in the Western Isles of Scotland. Unpublished doctoral thesis, University of Edinburgh, Edinburgh, U.K.

Church, M.J. (2002b). Archaeobotanical considerations of a conflagration in Dun Bharabhat, Lewis. In B. Ballin-Smith \& I. Banks (Eds.), In the shadow of the brochs (pp.67-75). Stroud: Tempus.

Church, M.J., \& Gilmour, S.M.D. (1999). Guinnerso (Uig Parish). Discovery and Excavation in Scotland (1998), 106.

Church, M.J., Gilmour, S.M.D, \& Flitcroft, C. (1999). Gob Eirer (Uig Parish). Discovery and Excavation in Scotland (1998), 106-107.

Church, M.J., \& Peters, C. (2000). Sedimentary analysis of soil samples. In D.W. Harding \& T.N. Dixon, Dun Bharabhat, Cnip, an Iron Age settlement in West Lewis: Volume 1, structures and material culture (pp. 114-119). Calanais Research Monograph No. 2, Edinburgh: University of Edinburgh.

Church, M.J., \& Peters, C. (2004). Application of mineral magnetism in Atlantic Scotland archaeology 2: Archaeobotanical taphonomy in Atlantic Scotland. In R. Housley \& G.M. Coles (Eds.), Atlantic connections and adaptations: Economies, environments and subsistence in the North Atlantic realm (pp. 99-115). Oxford: Oxbow.

Dalan, R.A., \& Banerjee, S.K. (1998). Solving archaeological problems using techniques of soil magnetism. Geoarchaeology, 13, 3-36.

Dewar, I., Batt, C.M., \& Peters, C. (2002). A mineral magnetic investigation into fuel derived deposits from Old Scatness Broch, Shetland. Physics and Chemistry of the Earth, 27, 1343-1348.

Dickson, C. (1994). Plant remains. In B. Ballin Smith (Ed.), Howe: Four millennia of Orkney prehistory (pp. 125-139). Society of Antiquaries of Scotland Monograph Series No. 9. Edinburgh: Society of Antiquaries.

Dickson, C. (1998). Past uses of turf in the Northern Isles. In C. Milles \& G.M. Coles (Eds.), Life on the edge: Settlement in marginal areas (pp. 105-109). Oxford: Oxbow.

Dickson, C.A., \& Dickson, J.H. (2000). Plants and people in ancient Scotland. Stroud: Tempus Publishing.

Dickson, J. (1992). North American driftwood, especially Picea (spruce), from archaeological sites in the Hebrides and Northern Isles of Scotland. Review of Palaeobotany and Palynology, 73, 49-56.

Dixon, W.J., (Ed.) (1985). BMDP Statistical Software Manual. Berkeley, CA: University of California.

Dockrill, S.J., Turner, V.E., \& Bond, J.M. (2001). Old Scatness/Jarlshof Environs Project. Discovery and Excavation in Scotland, New Series Vol. 1 (2000), 79-81.

Englike, H. (1991). Observations on the structures and formation of microscopic smithing residues from Bixby Blacksmiths shop at Barre Four Corners, Massachussetts, 1824-1855. Journal of Historical Metallurgy, 25, 92-98.

Faßbinder, J.W.E., \& Stanjek, H. (1993). Occurrence of bacterial magnetite in soils from archaeological sites. Archaeologia Polona, 31, 117-128.

Fenton, A.S. (1978). The Northern Isles: Orkney and Shetland. Edinburgh: John Donald.

Fossitt, J.A. (1996). Late Quaternary vegetation history of the Western Isles of Scotland. New Phytologist, $132,171-196$.

Gilbertson, D.D., Kent, M., \& Grattan, J. (1996). The Sheffield environment and archaeology research campaign in the Outer Hebrides. In D.D. Gilbertson, M. Kent, \& J. Grattan (Eds.), The Outer Hebrides: The last 14,000 years (pp. 1-4). Sheffield: Sheffield Academic Press.

Grattan, J., Gilbertson, D.D., \& Pyatt, B. (1996). Geochemical investigations of environmental change in the Outer Hebrides. In D.D. Gilbertson, M. Kent, \& J. Grattan (Eds.), The Outer Hebrides: The last 14,000 years (pp. 27-44). Sheffield: Sheffield Academic Press. 
Gribble, C.D. (1994). The geology of the Outer Hebrides. In R.J. Pankhurst \& J.M. Mullin (Eds.), Flora of the Outer Hebrides (pp. 14-18). London: HMSO.

Harding, D.W. (2000). The Hebridean Iron Age: Twenty years research. Department of Archaeology Occasional Paper 20, Edinburgh: University of Edinburgh.

Harding, D.W., \& Armit, I. (1990). Survey and excavation in West Lewis. In I. Armit (Ed.), Beyond the brochs: Changing perspectives on the Atlantic Scotland Iron Age (pp. 71-107). Edinburgh: Edinburgh University Press.

Harding, D.W., \& Dixon, T.N. (2000). Dun Bharabhat, Cnip, an Iron Age settlement in West Lewis: Volume 1, structures and material culture. Calanais Research Monograph No. 2, Edinburgh: University of Edinburgh.

Harding, D.W., \& Gilmour, S.M.D. (2000). The Iron Age settlement at Beirgh, Riof, Isle of Lewis: Excavations, 1985-1995, Volume 1: The structures and stratigraphy. Calanais Research Monograph No. 1, Edinburgh: University of Edinburgh.

Hodder, I. (1990). The Domestication of Europe. Oxford: Blackwell.

Jones, M. (1991). Sampling in palaeoethnobotany. In W. van Zeist, K. Wasylikowa, \& K-E. Behre (Eds.), Progress in Old World palaeoethnobotany (pp. 53-62). Rotterdam: Balkema.

Kenward, H. K., Hall, A. R., \& Jones, A. K. G. (1980). A tested set of techniques for the extraction of plant and animal macrofossils from waterlogged archaeological deposits. Science and Archaeology, 22, 3-15.

Linford, L.T. (2000). Evidence of domestic fires in antiquity: A mineral magnetic approach based on recent experimental samples. IRM Quarterly, 9, Visiting Fellow's Report.

Lomax, T.M. (1997). Holocene vegetation history and human impact in western Lewis, Scotland. Unpublished doctoral dissertation, University of Birmingham, Birmingham, U.K.

Maher, B.A., \& Thompson, R. (1999). Quaternary climates, environments and magnetism. Cambridge: Cambridge University Press.

Marshall, P., Mulville, J., Parker-Pearson, M., Smith, H., \& Ingram, C. (2000). Cladh Hallan (South Uist Parish). Discovery and Excavation in Scotland (1999), 91-93.

Martin, M. (1716). A description of the Western Isles of Scotland. London: Mercat Press.

McClean, R., \& Kean, W. (1993). Contributions of wood ash magnetism to archaeomagnetic properties of fire pits and hearths. Earth and Planetary Science Letters, 119, 387-394.

McLaughlin, K. (1980). Traditional fuels of the Outer Hebrides: The modern charred seed assemblages. Unpublished master's thesis, University of Sheffield, Sheffield, U.K.

Miller, N.F., \& Smart, T.L. (1984). Intentional burning of dung as fuel: A mechanism for the incorporation of charred seeds into the archaeological record. Journal of Ethnobiology 4, 15-28.

Morinaga, H., Inokuchi, H., Yamashita, H., Ono, A., \& Inada, T. (1999). Magnetic detection of heated soils at Palaeolithic site in Japan. Geoarchaeology, 14, 377-399.

Munsell Soil Color Charts. (1992). New York: Kollmorgen Instruments Corporation.

Neighbour, T., \& Burgess, C. (1997). Bostadh (Uig Parish). Discovery and Excavation in Scotland (1996), $113-114$.

Neighbour, T., \& Church, M.J. (2001). Galson multi-phase settlement (Barvas Parish). Discovery and Excavation in Scotland, New Series Vol. 1 (2000), 94.

Neighbour, T., Knott, C., \& Gregg, M. (2001). A long cist cemetery at Galson, Isle of Lewis. Proceedings of the Society of Antiquaries of Scotland, 130, 559-584.

Nicholson, R.A., \& Dockrill, S.J. (Eds.) (1998). Old Scatness Broch, Shetland: Retrospect and Prospect. Bradford Archaeological Sciences Research Monograph 5/NABO Monograph No.2, Bradford: University of Bradford/Shetland Amenity Trust/North Atlantic Biocultural Organization.

Parker-Pearson, M., \& Sharples, N. (Eds.) (1999). Between land and sea: Excavations at Dun Vulan, South Uist. Sheffield: Sheffield Academic Press.

Pearsall, D. (2000). Palaeoethnobotany (2nd ed.). New York: Thames and Hudson.

Peters, C., \& Thompson, R. (1999). Supermagnetic enhancement, superparamagnetism, and archaeological soils. Geoarchaeology, 14(5), 401-413.

Peters, C., Church, M.J., \& Coles, G.M. (2000). Mineral magnetism and archaeology at Galson on the Isle of Lewis, Scotland. Physics and Chemistry of the Earth, 25, 455-460.

Peters, C., Church, M.J., \& Mitchell, C. (2001). Investigation of domestic fuel sources on Lewis using mineral magnetism. Archaeological Prospection, 8, 227-237. 


\section{CHURCH ET AL.}

Peters, C., \& Batt, C. M. (2002). Dating and sourcing fuel ash residues from Cladh Hallan, south Uist, Scotland, using mineral magnetic techniques. Physics and Chemistry of the Earth, 27, 1349-1353.

Peters, C., Thompson, R., Harrison, A., \& Church, M.J. (2002). Low temperature magnetic characterization of fire ash residues. Physics and Chemistry of the Earth, 27, 1355-1361.

Peters, C., Church, M. J., \& Batt, C. (2004). Application of mineral magnetism in Atlantic Scotland archaeology 1: Techniques, magnetic enhancement and the identification of fuel sources. In R. Housley \& G.M. Coles (Eds.), Atlantic connections and adaptations: Economies, environments and subsistence in the North Atlantic realm (pp. 86-95). Oxford: Oxbow.

Piggott, S. (1966). A scheme for the Scottish Iron Age. In A.L.F. Rivet (Ed.), The Iron Age in Northern Britain (pp. 1-15). Edinburgh: Edinburgh University Press.

Schweingruber, F. H. (1990). Microscopic wood anatomy. Geneva: Swiss Federal Institute for Forest, Snow and Landscape Research.

Schwenninger, J.-L. (1999). The soil micromorphology. In M. Parker-Pearson \& N. Sharples (Eds.), Between land and sea: Excavations at Dun Vulan, South Uist (pp. 336-342). Sheffield: Sheffield Academic Press.

Sim, D. (1998). Beyond the bloom: Bloom refining and iron artefact production in the Roman world. Oxford: British Archaeological Reports International Series No. 725.

Simpson, I.A., Vésteinsson, O., Adderley, W.P., \& McGovern, T.H. (2003). Fuel resource utilization in landscapes of settlement. Journal of Archaeological Science, 30, 1401-1420.

Smith, W. (1998). Fuel for thought: Archaeobotanical evidence for the use of alternatives to wood fuel in Late Antique North Africa. Journal of Mediterranean Archaeology, 11, 191-205.

Smith, H. (1999). The plant remains. In M. Parker-Pearson \& N. Sharples (Eds.), Between land and sea: Excavations at Dun Vulan, South Uist (pp. 297-335). Sheffield: Sheffield Academic Press.

Stace, C. (1994). New flora of the British Isles (2nd ed.). Cambridge: Cambridge University Press.

Thompson, R., \& Oldfield, F. (1986). Environmental magnetism. London: Allen \& Unwin.

Turner, V. (1998). The shaping of Shetland. Lerwick: Shetland Times.

van der Veen, M. (1992). Crop husbandry regimes: An archaeobotanical study of farming in Northern England, 1000 BC-AD 500 (Sheffield Archaeological Monographs 3). Sheffield: Collis Publications.

Walden, J., Oldfield, F., \& Smith, J.P. (1999). Environmental magnetism: A practical guide. Technical Guide No. 6, London: Quaternary Research Association.

Yates,G. (1988). Environmental magnetism applied to archaeology. Unpublished doctoral dissertation, University of Liverpool, Liverpool, U.K.

Received November 20, 2005

Accepted for publication January 11, 2007 